\title{
POVERTY ALLEVIATION THROUGH THE ROLE OF WOMEN'S SOCIAL CAPITAL
}

\author{
Putri Suci Asriani $^{1)}$; Yessilia Osira ${ }^{2)}$ \\ 1) Department of Agricultural Socio-Economics, Faculty of Agriculture, University of \\ Bengkulu \\ 2) Department of Social Welfare, Faculty of Social and Politic Science, University of \\ Bengkulu \\ Email: ${ }^{1)}$ putriasriani@unib.ac.id
}

How to Cite :

Asriani, P.S., Y Osira, 2019. The Role of Women's Social Capital in Poverty Alleviation Effort. Journal of Agri Socio-Economics and Business. 1 (1): 3944 DOI: https://doi.org/10.31186/jaseb.1.1.39-44

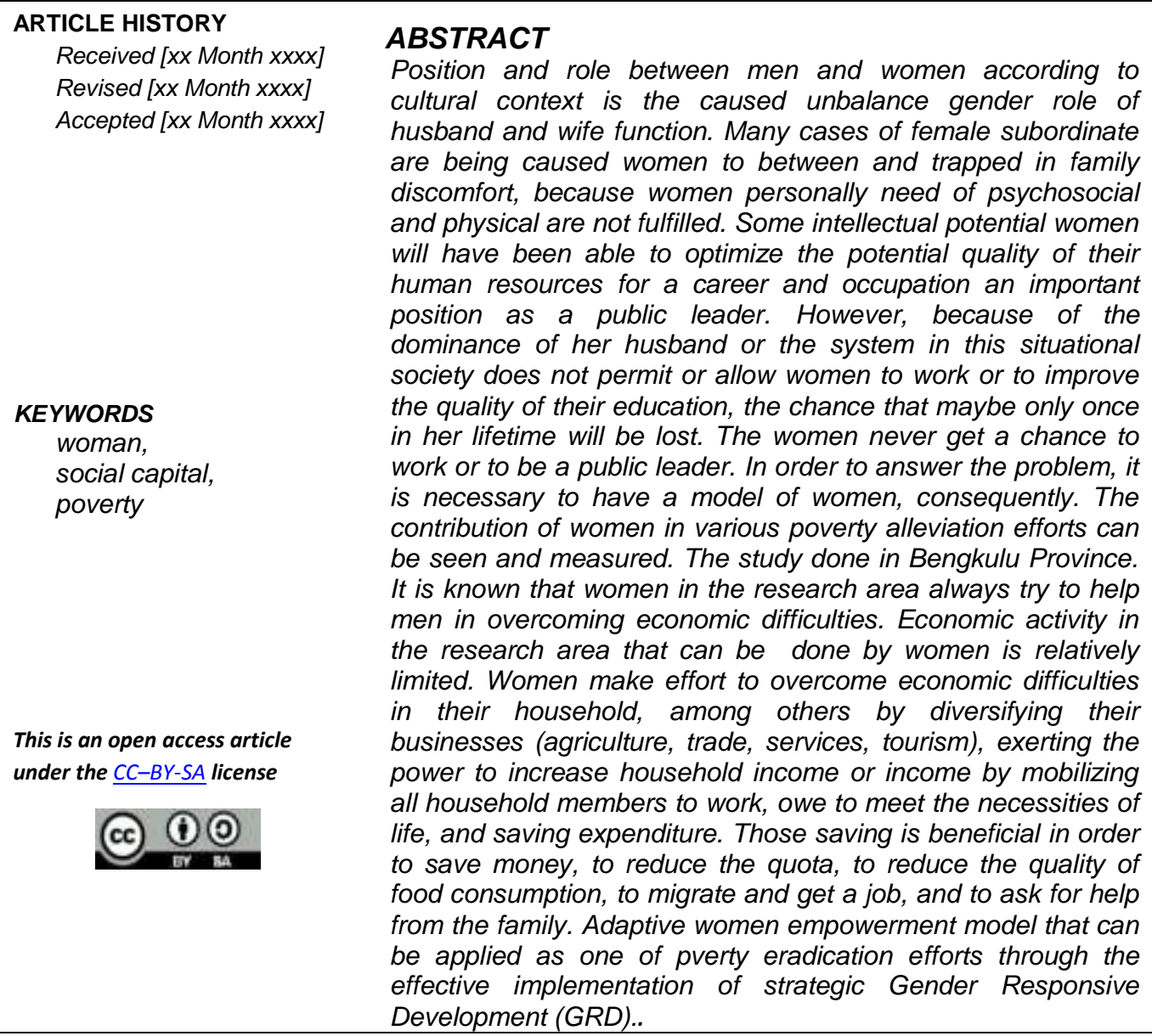




\section{INTRODUCTION}

In relation to family poverty, conscious or unconscious must be understood that the root cause of the problem of poverty is gender inequality and injustice to family and community. The decision making about various household activity to realize family goals is not optimal, inefficient and ineffective, because there is irregularity in the management of time and work and financial management between husband, wife and children. Broadly speaking the word "gender" can be interpreted as the differences in the roles, functions, status and responsibilities of men and women as a result of sociocultural constructs (construction) embedded through the process of socialization from one generation to the next.

Women have relation with poverty, where patriarchal culture has indirectly given restrictions on women and injustice and inequality contributed to the proximate of women's identity to poverty. The experiences of women and men are different to poverty, and women are far behind compared than men in accessing economic resources as a doorway to the elimination of injustices in society. This is in line with those found by Birdshal and McGreevey (1983) which state the fact that the burden of poor women is greater because of the dual role of housekeeper as well as breadwinner for the family. Women are responsible for taking care of children, preparing food, taking water and firewood, washing clothes, cleaning house, managing household finance, which absorb most of their time. However, this work is often not considered a "job", so it is not counted in the "production" of a household. This is exacerbated by the assumption that the income of women only as an "additional" husband's income.

The position and roles of men and women was according to cultural contexts cause the imbalance of gender roles between husband and wife. Many cases of female subordinate put women in a weak position and the woman are caught in the family inconvenience situation, because personally a woman is not fulfilled all her psychosocial and physical needs. Women should be able to optimize the potential quality of their human resources for a career and occupy an important position as a public leader, because women have special intellectually potential. However, because of the dominance of her husband or the system in society that does not allow or allow women to work or to improve the quality of her education, then the opportunity that may be only once in a lifetime will be lost, and the woman never gets a chance to work or be a leader on the public sector. To answer the problem, it is necessary to have a model of women empowerment that can accommodate various roles of women, so that the contribution of women in various poverty alleviation efforts can be seen and measured.

\section{RESEARCH METHODS}

\section{Method and Location}

The research was done by using descriptive method, the descriptive method applied ex-post facto method. According to Travers (1978) in Umar (2008) explained this method aims to describe the nature of something on the going research done and examine the causes of a particular symptom. According to Gay (1976) in Umar (2008), this study goes determining the consequences and finding the cause. According Kerlinger (1976) in Umar (2008), this study is a systematic empirical search in which the researcher no available control the free variable, because the event has occurred or because of its nature no to be manipulated. So the study using the ex-post facto 
method. The ex-post facto method is a method to studying a problems and phenomenon, initially observes as the consequences and then tries to determine the cause.

The location of research is determined purposively by considering the distribution of the region and socio-cultural background of the people of Bengkulu Province, Indonesia. In order to optimize the opportunities and probability, the survey and observation sites was determined in three different geographical areas, namely coastal areas, mountains, and plantations. The division of these three areas had based on the background of different livelihood and cultural pattern.

\section{Procedure of Research and Measurment}

Stage of the research process undertaken are (Asriani, 2017):

1. Mapping the role of women in poverty alleviation, with indicator: to evaluate existing the role of women, socialization, social emphasis, and the power of authority approach.

2. Survey of various efforts to alleviate poverty, with indicator: introduction to the various roles of women in society, unraveling belief and self-values, exploring barriers and personal growth, respect differences, making a plans, and creating simple and flexible activity.

3. Factor identifications

4. Mapping the role women empowerment alternative

5. Evaluate the role women empowerment

6. Formulation the role women empowerment

Women's empowerment is key in efforts to eradicate impoverishment of women and can be one of the easier alternative policies. This step is an attempt to address the problem of role inequality between women and men influenced by various norms prevailing in society, religious interpretation and socio-cultural constructions that govern role allocation, attributes, stereotypes, rights, duties, responsibilities and perceptions of men and women.

\section{RESULTS AND DISCUSSION}

\section{The Role of Women in Poverty Reduction}

Mapping the role of women in poverty alleviation is done through the analysis and study of the six main components of the implementation process various activity women in the domestic, public and economic sectors. These six key components include the existing role of women, socialization, social emphasis, power of authority approaches, information strategic, and society participation. Based on the results of data analysis in this research presented in Table 1. Table 1 explained results of analysis of the role of women in poverty alleviation with a sample of 23 women productive activities $(\mathrm{Pr})$ and 23 women engaged in non-productive activities (N-Pr) with score indicators: very many improvement-VMI $(1,00-1,75)$, many improvement-MI $(1,76-2,51)$, improvement-I $(2,52-3,27)$, and little improvement-LI $(3,28-4,00)$. 
Table 1.

The Results of Mapping Women's Roles and Poverty Reduction in Bengkulu Province, Indonesia in 2017

\begin{tabular}{|c|c|c|c|c|c|c|c|}
\hline \multirow[t]{2}{*}{ No } & \multirow[t]{2}{*}{ The Roles Indicator } & \multicolumn{2}{|c|}{$\begin{array}{c}\text { Frequency } \\
\text { (population) }\end{array}$} & \multicolumn{2}{|c|}{ Percentage (\%) } & \multicolumn{2}{|c|}{ Average (Score) } \\
\hline & & $\operatorname{Pr}$ & N-Pr & $\operatorname{Pr}$ & N-Pr & $\operatorname{Pr}$ & $\mathrm{N}-\mathrm{Pr}$ \\
\hline \multirow[t]{6}{*}{1.} & $\begin{array}{l}\text { Existing women } \\
\text { roles }\end{array}$ & & & & & & \\
\hline & VMI & 5 & 20 & 21,74 & 86,96 & 2,47 & 1,54 \\
\hline & MI & 4 & 2 & 17,39 & 8,70 & & \\
\hline & I & 12 & 0 & 52,17 & 0 & I & VMI \\
\hline & LI & 2 & 1 & 8,70 & 4,35 & & \\
\hline & Sum & 23 & 23 & 100 & 100 & & \\
\hline \multirow[t]{6}{*}{2.} & Socialization & & & & & & \\
\hline & VMI & 6 & 17 & 26,09 & 73,91 & 2,13 & 1,37 \\
\hline & MI & 11 & 5 & 47,82 & 21,74 & & \\
\hline & I & 5 & 1 & 21,74 & 4,35 & MI & VMI \\
\hline & LI & 1 & 0 & 4,35 & 0 & & \\
\hline & Sum & 23 & 23 & 100 & 100 & & \\
\hline \multirow[t]{6}{*}{3.} & $\begin{array}{l}\text { Social emphasis } \\
\text { VMI }\end{array}$ & & & & & & \\
\hline & MI & 15 & 7 & 65,22 & 30,43 & 1,63 & 1,85 \\
\hline & I & 6 & 16 & 26.09 & 69,57 & & \\
\hline & LI & 0 & 0 & 0 & 0 & VMI & MI \\
\hline & & 2 & 0 & 8,70 & 0 & & \\
\hline & Sum & 23 & 23 & 100 & 100 & & \\
\hline \multirow[t]{6}{*}{4.} & $\begin{array}{l}\text { The power of } \\
\text { authority approach } \\
\text { VMI }\end{array}$ & & & & & & \\
\hline & MI & 10 & 16 & 43,48 & 69,57 & 2,12 & 1,16 \\
\hline & I & 4 & 1 & 17,39 & 4,35 & & \\
\hline & LI & 2 & 5 & 8,70 & 21,74 & MI & VMI \\
\hline & & 7 & 1 & 30,43 & 4,35 & & \\
\hline & Sum & 23 & 23 & 100 & 100 & & \\
\hline \multirow[t]{6}{*}{5.} & $\begin{array}{l}\text { Information } \\
\text { strategic }\end{array}$ & & & & & & \\
\hline & VMI & 13 & 21 & 56,52 & 91,30 & 1,34 & 0,97 \\
\hline & MI & 7 & 2 & 30,43 & 8,70 & & \\
\hline & I & 3 & 0 & 13,04 & 0 & VMI & VMI \\
\hline & LI & 0 & 0 & 0 & 0 & & \\
\hline & Sum & 23 & 23 & 100 & 100 & & \\
\hline \multirow[t]{6}{*}{6.} & $\begin{array}{l}\text { Society } \\
\text { participation }\end{array}$ & & & & & & \\
\hline & VMI & 13 & 21 & 56,52 & 91,30 & 1,57 & 0,65 \\
\hline & MI & 7 & 2 & 30,43 & 8,70 & & \\
\hline & I & 3 & 0 & 13,04 & 0 & VMI & VMI \\
\hline & LI & 0 & 0 & 0 & 0 & & \\
\hline & & 23 & 23 & 100 & 100 & & \\
\hline
\end{tabular}

Source: Primary data from analysis result (2017)

The dominant role of women in society is the participation of women in various domestic roles, whether women who are productive or non-productive. However, for women with productive activities, they have an excellent opportunity to participate in various economic roles, following by participation in various public roles. The average 
woman in the activity, both productive and non-productive already have a place to express opinion, although still require many evaluation and correction.

In general, the result study can be conveyed that the process of mapping the role of women, whether for women with productive activity or not, still needs improvement. The role of women in the productive sector against poverty alleviation still requires considerable improvement (based on an average score of 1.88 from scale 4), whereas for women without productive activity, their role in poverty alleviation still requires considerable improvement too (based on average score) average 1.26 from scale 4).

\section{Formulation The Role of Women Empowerment}

Based on the results of the study has been done in Bengkulu Province, it is known that women in the research area always try to help men overcome economic difficulties. Economic activity in the research area that can be done by women is relatively limited. Women make efforts to overcome economic difficulties in their households, among others, by diversifying businesses (agriculture, trade, services, tourism), mobilizing the power to increase household income or income by mobilizing all household members to work, owed to meet the needs live, save on spending to save, cut food, reduce the quality of food consumption, migrate to get a job, and ask for help from the family.

Adaptive women empowerment model can be applied as one of poverty eradication efforts is through the effective implementation of Gender Responsive Development (PRG) strategy. The home industry has great potential to strengthen the economic resilience of the family because as a production system it can increase the added value of local resources in the scale of micro enterprises spread throughout the region, both in urban and rural areas. As a home industry activist, it is expected that the role of women in the domestic and public aspects can be balanced.

\section{CONCLUSIONS AND POLICY IMPLICATIONS}

\section{Conclusions}

Women's social capital in poverty alleviation are:

1. Women empowerment activities undertaken in the village;

2. Empowerment activities involving the general population (men, women and children), and village devices;

3. Provide forum of women empowerment in village;

4. Provide place activity and gathering for women as housewives;

5. Determine active participants as key activists/activists in various empowerment activity;

6. Provide place of activity and gathering for women as public workers;

7. Provide place of activity and gathering for women as economic activity; and

8. Design of activity devoted housewives in manage of their public activity.

\section{Recommendations}

There are two important points in the improvement of untapped roles (suggestions based on the results of the review), namely: 
1. Empowerment activity aimed at housewives manage of their domestic activity; and

2. Empowerment activity aimed at housewives manage of their economic activity.

\section{REFERENCES}

Asriani, Putri Suci, "Kajian Perumusan Model Pengentasan Kemiskinan melalui Pemberdayaan Perempuan di Provinsi Bengkulu," Research Report, in press, 2017, pp. 17-20.

Birdsall, Nancy, and William McGreevey, "Women, poverty and development. In Women and Poverty in the Third World, ed. Myra Buvinic, Margaret Lycette, and William McGreevey," Baltimore: Johns Hopkins University Press, 1983, pp 3-13.

Gay, L.R., Geoffrey E Mills and Peter Airasian, "Educational Research: Competencies for Analysis and Applications," Vital Source (for Pearson), 2015.

Gebremedhin, Tesfa G., and Luther G. Tweeten, "Research Methods and Communication in the Social Sciences, Greenwood Publishing Group, Inc., 1984, pp.14-15.

Umar, Husein, "Riset Sumberdaya Manusia dalam Organisasi Ed. Revisi (Perluasan)," Penerbit PT. Gramedia Pustaka Utama. Jakarta-Indonesia, 2005, pp. 86. 